\title{
Fabrikasi Tempat Sampah Pintar Dengan Pemilahan dan Pemadatan Otomatis
}

\author{
Amrina Mustaqim ${ }^{1}$, Sefrani IG Siregar ${ }^{2}$, Syamsyarief Baqaruzi ${ }^{3}$ \\ ${ }^{1,2}$ Program Studi Teknik Fisika, Institut Teknologi Sumatera \\ ${ }^{3}$ Program Studi Teknik Elektro, Institut Teknologi Sumatera \\ ${ }^{1}$ amrina.mustaqimetf.itera.ac.id, ${ }^{2}$ isdarmaya.gokmariadtf.itera.ac.id \\ ${ }^{3}$ syamsyarief.baqaruzidel.itera.ac.id
}

\begin{abstract}
Abstrak - Sampah telah menjadi persoalan yang paling utama hingga saat ini. Pengelolaan sampah terutama sampah plastik, yang tidak optimal bisa menyebabkan pencemaran lingkungan dan juga penyusutan lahan. Pengelolaan sampah di Indonesia dilakukan dengan sistem end of pipe, sehingga terjadi penumpukan sampah di tiap lokasi pengumpulan. Tempat sampah pintar ini dibuat khusus untuk sampah plastik yang nanti akan dikompresi sehingga dihasilkan sampah dengan volume yang lebih kecil dan dapat mengurangi proses penyusutan lahan. Pada tempat sampah ini terdapat tiga sistem utama. Sistem pemilahan sampah, sistem pemantauan daya tampung tempat sampah, dan sistem pemanas sampah. Hasil dari Ketiga sistem tersebut adalah tempat sampah pintar dapat bekerja secara optimal dengan rata-rata error $<5 \%$.
\end{abstract}

Kata kunci: sampah, plastik, tempat sampah, sistem

Abstract-Garbages has become the main problem until now. Waste management, especially plastic waste, which is not optimal can cause environmental pollution and also land shrinkage. Waste management in Indonesia is carried out using an end of pipe system, resulting in accumulation of waste at each collection points. This smart trash bin is specially made for plastic waste which would later be compressed so that a smaller volume of plastics waste are produced and can reduce the process of land shrinkage. In this trash bin there are three main systems. Garbages sorting system, trash bin capacity monitoring system, and garbage heating system. The result of the three systems is that the smart trash can work optimally with an average error of $<5 \%$.

Keywords: garbages, plastics, trash bin, system

\section{Pendahuluan}

Permasalahan akan sampah tidak akan pernah habis untuk dikaji serta dibahas. Hasil data dari worldbank [1], sampah dihasilkan sekitar 2 triliun ton setiap tahun sehingga dapat diasumsikan setiap orang yang ada di dunia menghasilkan sampah sekitar 0,74-4,54 kilogram setiap hari bergantung pada negara tersebut. Dari keseluruhan sampah tersebut, komposisi sampah plastik yang paling mendominasi yaitu $44 \%$ dari total sampah yang dihasilkan. Menurut Sano (2019) [2], Indonesia menghasilkan sampah 175 ribu ton setiap harinya dan sekitar 24,5 ribu atau $14 \%$ berupa sampah plastik. Sampah plastik sendiri diklasifikan menjadi 7 berdasarkan tipenya. Tipe plastik tersebut antara lain PET, HDPE, PVC, LDPE, PP, PS dan lainnya [3]

Penelitian tentang treatment sampah plastik telah banyak dilakukan. Mulai dari secara kimiawi [4]menggunakan mikrobiologi [5], enzim, hingga katalis [6] [7]. Semua penelitian tersebut dilakukan untuk mempercepat proses degradasi dari plastik. Sedangkan pengelolaan sampah plastik non-treatment dapat dilakukan dengan 3 cara yaitu, reduction (mengurangi) recycle (mendaur ulang), dan recovery, recovery disini artinya sampah plastik tersebut jangan sampai merusak sistem recovery dari alam seperti masuk kealiran sungai hingga laut [8]. Pengelolaan sampah yang kurang efektif dan efisien mengakibatkan bahaya bagi kesehatan manusia maupun lingkungan sekitar [9] [10].

Pengelolaan sampah di Indonesia mayoritas menggunakan pendekatan akhir (end of pipe). Proses ini dilakukan dengan cara sampah dikumpulkan di suatu lokasi kemudian akan diangkut dan dibuang ke tempat pembuangan akhir (TPA) [11] Proses ini akan sangat memberatkan TPA dikarenakan sampah tercampur baur dan pengolahan sampah dilakukan dengan cara pembakaran sehingga akan menimbulkan polusi udara dan juga sisa pembakaran akan menimbulkan sampah baru yang menyebabkan penyusutan lahan. Pembuatan tempat sampah pintar ini diharapkan mampu mengurangi proses di TPA dikarenakan sampah akan dipilah dan akan di press untuk mengurangi volume dari sampah plastik yang dihasilkan. Sehingga selain dapat mengurangi polusi, penyusutan lahan pun dapat diatasi.

Penggunaan sensor untuk memilah sampah karena mayoritas diindonesia tidak patuh terhadap regulasi yang diberikan pemerintah sehingga tempat sampah yang smart yang hanya mau menerima sampah plastik perlu dibuat. Sensor yang digunakan adalah sensor yang sederhana serta murah dan mudah didapatkan digunakan dalam pembuatan tempat sampah ini. 


\section{PERANCANGAN SISTEM}

Proses pembuatan tempat sampah terdiri dari tiga tahapan. Tahap Awal, tahap perancangan dan tahap implementasi.

\section{A. Tahap awal}

Pada tahapan ini dilakukan pemilihan jenis sampah yang bisa diterima oleh tempat sampah pintar tersebut. Dikarenakan sampah plastik paling banyak dihasilkan dan juga memiliki titik leleh yang rendah dan mudah dipadatkan, penulis memilih sampah plastik yang dipilih dan dipadatkan.

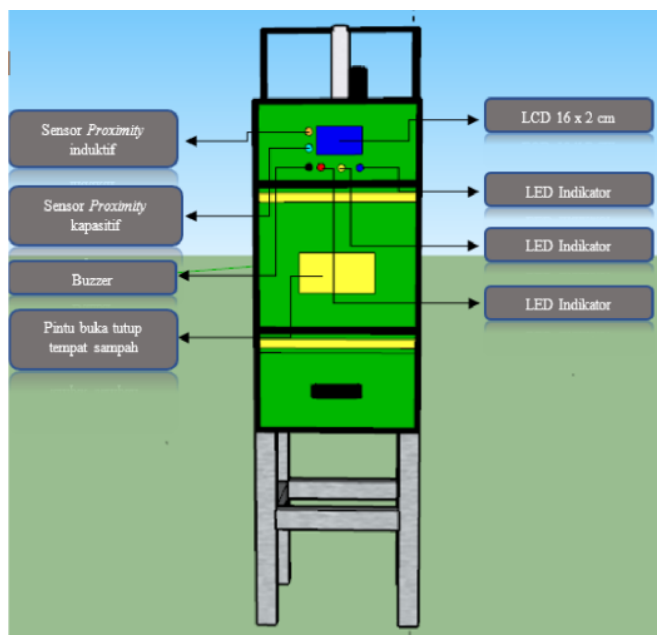

Gambar 1. Desain Tempat Sampah Pintar

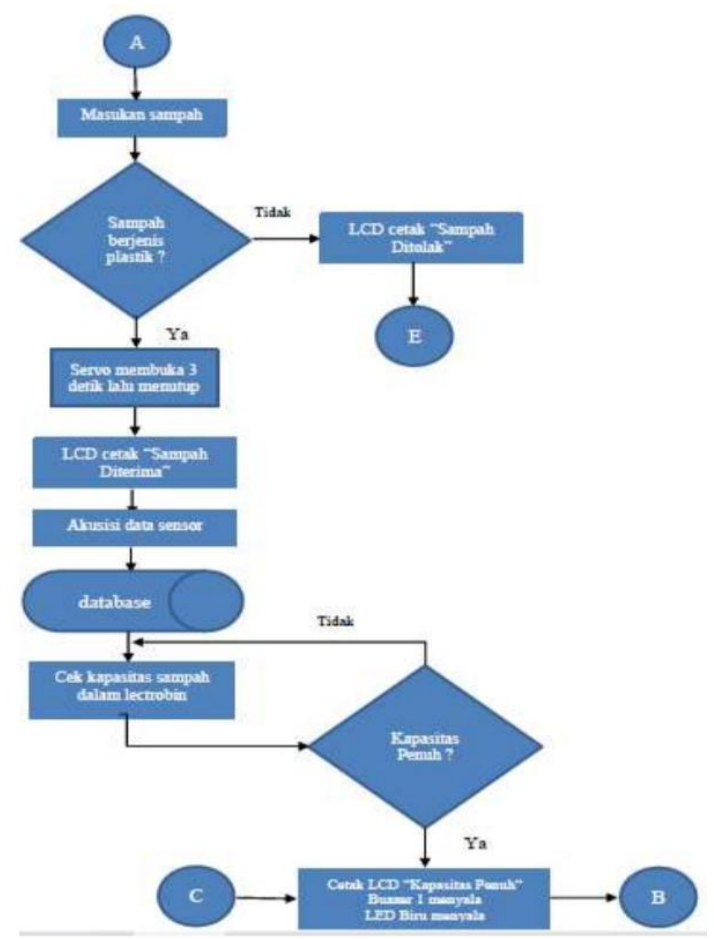

Gambar 2. Diagram Alir Sistem Tempat Sampah Pintar

\section{B. Tahap Perancangan}

Pada proses perancangan ini dilakukan 2 tahap. Tahap pertama merupakan desain tempat sampah dan yang kedua adalah fabrikasi tempat sampah

\section{Desain tempat sampah}

Pada proses ini dilakukan desain tempat sampah yang ergonomis dan juga pemilihan sensor yang digunakan supaya mudah dalam proses pembuatannya dan murah. Desain tempat sampah dapat dilihat pada gambar 1. Pada sampah tersebut terdapat 3 sensor utama, yang pertama sensor pemilihan sampah dalam hal ini hanya plastik yang diperbolehkan, yang ke dua sensor untuk mengetahui kapasitas sampah pada tempat pengumpulan. Yang ke tiga sensor suhu untuk mengetahui suhu pemanasan pada tempat sampah tersebut.

\section{Fabrikasi tempat sampah}

Pada proses fabrikasi ini dibuatlah tempat sampah sesuai dengan desain yang telah dibuat. Serta pemasangan sensor yang akan digunakan.

Untuk Sensor pemilihan sampah digunakan 2 sensor yaitu sensor proksimity induktif dan kapasitif. Sensor induktif berfungsi untuk mendeteksi logam dan sensor kapasitif berfungsi untuk mendeteksi sampah logam maupun non-logam. Untuk sensor kedua yaitu menggunakan sensor ultrasonik untuk menentukan kapasitas tampung pada tempat sampah dan yang terakhir termokopel untuk mengetahui suhu pada saat proses pemanasan dilakukan. Proses selanjutnya perakitan semua komponen tersebut dan terbentuklah tempat sampah pintar.

\section{Tahap Implementasi}

Proses implementasi dilakukan sesuai dengan diagram alir yang telah dibuat seperti pada gambar 2. Dari proses tersebut tempat sampah pintar sudah dapat digunakan.

\section{HASIL DAN PEMBAHASAN}

Tempat sampah pintar berhasil dibuat seperti pada gambar 3 . Pembuatan tempat sampah ini menggunakan tiga sistem utama. Sistem pemilihan sampah menggunakan sensor proximity induktif dan kapasitif. Sistem penentuan kapasitas tampung menggunakan sensor ultrasonik. Sistem pengecekan suhu menggunakan thermokopel.

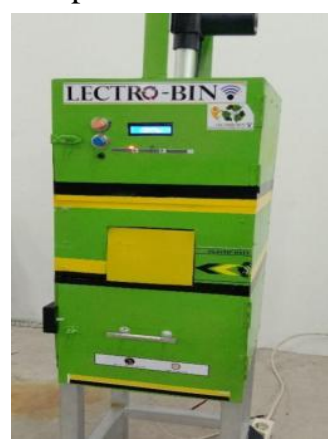

Gambar 3. Tempat Sampah Pintar 
Pada proses ini dilakukan upaya untuk mengoptimalkan sistem kerja dari tempat sampah tersebut. Berikut hasil uji coba yang telah dilakukan pada masing-masing system

\section{A. Sistem Pemilihan Sampah}

Pengujian sistem pemilihan sampah dilakukan dengan 2 tahapan. Tahap pertama pengukuran jarak antara sensor dengan sampah dan juga tegangan yang dihasilkan, Tahap kedua kemampuan sensor dalam memilah sampah. Pada proses pengujian jarak digunakan sensor proksimiti (S.P) kapasitif dikarenakan sensor ini dapat mendeteksi logam maupun non logam. Sedangkan untuk pemilihan sampah plastik menggunakan sensor proksimity induktif dikarenakan sensor ini hanya mendeteksi logam. Hal ini disebabkan sensor proksimity induktif memiliki prinsip induktansi sehingga benda yang memiliki sifat induktif yang akan terdeteksi. Sedangkan sensor kapasitif hampir bisa mendeteksi semua benda karena memiliki prinsip kapasitif. Nilai tegangan yang dihasilkan S.P kapasitif ini ketika mendeteksi benda adalah 0 . Hal ini disebabkan S.P kapasitif memiliki tipe transistor NPN. Sedangkan S.P induktif memiliki tipe PNP sehingga ketika mendeteksi logam, nilai tegangan yang dihasilkan adalah $12 \mathrm{~V}$. Hasil pengukuran jarak dengan tegangan dilihat pada tabel 1 .

Tabel 1. Pengujian jarak dan tegangan pad S.P Kapasitif

\begin{tabular}{|c|c|c|c|}
\hline No & Jarak $(\mathbf{c m})$ & Tegangan $(\boldsymbol{V})$ & Status \\
\hline 1 & 0.1 & 0 & terdeteksi \\
\hline 2 & 0.2 & 0 & terdeteksi \\
\hline 3 & 0.3 & 0 & terdeteksi \\
\hline 4 & 0.4 & 0 & terdeteksi \\
\hline 5 & 0.5 & 0 & terdeteksi \\
\hline 6 & 0.6 & 0 & terdeteksi \\
\hline 7 & 0.7 & 0 & terdeteksi \\
\hline 8 & 0.8 & 0 & terdeteksi \\
\hline 9 & 0.9 & 0 & terdeteksi \\
\hline 10 & 1 & 0 & terdeteksi \\
\hline 11 & 1.1 & 0 & terdeteksi \\
\hline 12 & 1.2 & 12 & tidak terdeteksi \\
\hline 13 & 1.3 & 12 & tidak terdeteksi \\
\hline 14 & 1.4 & 12 & tidak terdeteksi \\
\hline 15 & 1.5 & 12 & tidak terdeteksi \\
\hline
\end{tabular}

Dari data tersebut dapat dilihat bahwa sensor proksimiti kapasitif berhasil mendeteksi dengan baik pada jarak kurang dari $1.1 \mathrm{~cm}$. Hal ini terlihat dengan tegangan yang dihasilkan sebesar $0 \mathrm{~V}$ sesuai dengan karakterisktik sensor proksimity kapasitif. Pada proses pengujian sampah pada sensor dapat dilihat pada tabel 2. Dari data tersebut dapat dilihat bahwa sensor mampu membedakan sampah plastik dengan sampah logam.

\section{B. Sistem Pemantauan Kapasitas Sampah}

Proses pengukuran dilakukan dua tahap. Tahap pertama pengukuran ketinggian sampah dan tahap kedua pengukuran ketika dilakukan kompresi dengan pemanas. Tabung sampah memiliki tinggi $20 \mathrm{~cm}$ dan tinggi maksimum plat kompresi sebesar $27 \mathrm{~cm}$. Hasil uji tahap pertama dapat dilihat pada tabel 3 dan pada saat dilakukan pemanasan dan dikompresi dapat dilihat pada tabel 4. Dari data tersebut didapatkan error sebesar $2.53 \%$ pada saat pengukuran normal tanpa kompresi sedangkan pada saat kompresi didapatkan nilai error sebesar $3.22 \%$ kenaikan error ini disebabkan panas yang dihasilkan pada saat proses kompresi.

Tabel 2. Pengujian Pemilihan Sampah

\begin{tabular}{|c|l|l|l|}
\hline No & \multicolumn{1}{|c|}{ Jenis Sampah } & \multicolumn{1}{|c|}{ S.P Induktif } & $\begin{array}{c}\text { S.P } \\
\text { Kapasitif }\end{array}$ \\
\hline 1 & $\begin{array}{l}\text { Plastik Jinjing } \\
\text { Bening, bewarna }\end{array}$ & tidak terdeteksi & terdeteksi \\
\hline 2 & Botol air mineral & tidak terdeteksi & terdeteksi \\
\hline 3 & $\begin{array}{l}\text { Plastik kemasan } \\
\text { sabun }\end{array}$ & tidak terdeteksi & terdeteksi \\
\hline 4 & $\begin{array}{l}\text { plastik makanan } \\
\text { ringan }\end{array}$ & tidak terdeteksi & terdeteksi \\
\hline 5 & $\begin{array}{l}\text { gelas plastik } \\
\text { minuman }\end{array}$ & tidak terdeteksi & terdeteksi \\
\hline 6 & botol saos & tidak terdeteksi & terdeteksi \\
\hline 7 & wadah plastik & tidak terdeteksi & terdeteksi \\
\hline 8 & $\begin{array}{l}\text { kaleng minuman } \\
\text { soda }\end{array}$ & terdeteksi & terdeteksi \\
\hline 9 & alumunium & terdeteksi & terdeteksi \\
\hline 10 & kaleng pylox & terdeteksi & terdeteksi \\
\hline
\end{tabular}

Tabel 3.Pengukuran Tinggi Menggunakan Sensor ultrasonik tanpa pemanasan

\begin{tabular}{|c|c|c|c|c|}
\hline No & $\begin{array}{c}\text { Tinggi } \\
\text { Real }(\mathbf{c m})\end{array}$ & $\begin{array}{c}\text { Tinggi } \\
\text { pengukuran }(\mathbf{c m})\end{array}$ & $\begin{array}{c}\text { Selisih } \\
(\mathbf{c m})\end{array}$ & $\begin{array}{c}\text { Error } \\
(\%)\end{array}$ \\
\hline 1 & 3 & 2.85 & 0.15 & 5.00 \\
\hline 2 & 5 & 4.78 & 0.22 & 4.40 \\
\hline 3 & 7 & 6.85 & 0.15 & 2.14 \\
\hline 4 & 9 & 9.32 & 0.32 & 3.56 \\
\hline 5 & 11 & 10.88 & 0.12 & 1.09 \\
\hline 6 & 13 & 13.33 & 0.33 & 2.54 \\
\hline 7 & 15 & 14.74 & 0.26 & 1.73 \\
\hline 8 & 17 & 17.65 & 0.65 & 3.82 \\
\hline 9 & 19 & 18.65 & 0.35 & 1.84 \\
\hline 10 & 21 & 20.74 & 0.26 & 1.24 \\
\hline 11 & 23 & 23.47 & 0.47 & 2.04 \\
\hline 12 & 25 & 24.56 & 0.44 & 1.76 \\
\hline 13 & 27 & 26.52 & 0.48 & 1.78 \\
\hline & & & & \\
\hline
\end{tabular}




\begin{tabular}{|c|c|}
\hline rata rata error & 2.53 \\
\hline
\end{tabular}

\section{Sistem pengukuran suhu}

Pengukuran suhu dilakukan dengan menempelkan thermokopel pada sisi tabung pemanas. Hasil pengukuran pada thermokopel dibandingkan dengan pengukuran menggunakan kamera termal. Hasil pengujian tersebut dapat dilihat gambar 4. Dari hasil pengujian tersebut didapatkan nilai error sebesar $1.77 \%$.

Tabel 4. Pengukuran Tinggi dengan pemanasan

\begin{tabular}{|c|c|c|c|}
\hline $\begin{array}{c}\text { Tinggi Real } \\
(\mathrm{cm})\end{array}$ & $\begin{array}{c}\text { Tinggi pengukuran } \\
(\mathrm{cm})\end{array}$ & Selisih (cm) & Error (\%) \\
\hline 2 & 2.12 & 0.12 & 6.00 \\
\hline 3 & 2.86 & 0.14 & 4.67 \\
\hline 4 & 3.85 & 0.15 & 3.75 \\
\hline 5 & 4.78 & 0.22 & 4.40 \\
\hline 7.5 & 7.92 & 0.42 & 5.60 \\
\hline 8.3 & 7.76 & 0.54 & 6.51 \\
\hline 9 & 8.84 & 0.16 & 1.78 \\
\hline 10 & 9.72 & 0.28 & 2.80 \\
\hline 12.5 & 12.32 & 0.18 & 1.44 \\
\hline 13 & 12.67 & 0.33 & 2.54 \\
\hline 14.5 & 14.83 & 0.33 & 2.28 \\
\hline 15 & 15.23 & 0.23 & 1.53 \\
\hline 16.3 & 16.56 & 0.26 & 1.60 \\
\hline 18 & 17.76 & 0.24 & 1.33 \\
\hline 20 & 20.42 & 0.42 & 2.10 \\
\hline & Rata-rata Error & & 3.22 \\
\hline
\end{tabular}

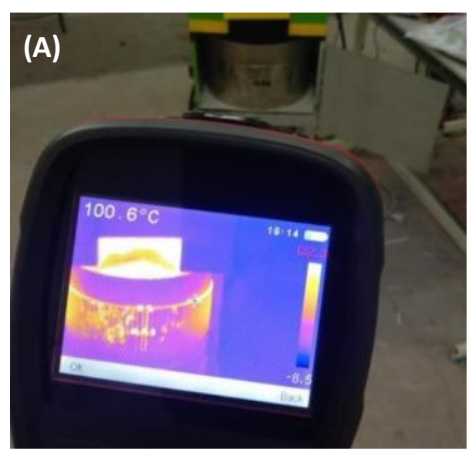

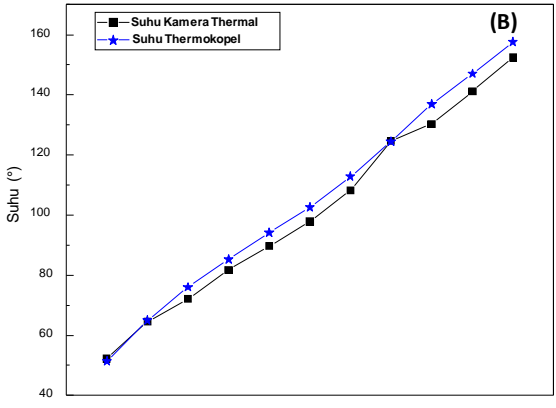

Gambar 4. A) pengukuran dengan kamera thermal B) grafik pengukuran antara sensor thermokopel dengan kamera thermal

\section{KESIMPULAN}

Tempat sampah pintar dengan pemilahan dan pemadatan otomatis telah berhasil dibuat. Sistem pemilihan sampah untuk mendapatkan sampah plastik dapat berjalan dengan baik. Sistem pemantauan kapasitas sampah dapat berjalan dengan optimal dengan error $<5 \%$ dan sensor suhu berjalan optimal dengan error $<2 \%$. Saran untuk penelitian selanjutnya adalah perlu digunakan sensor pemilahan lebih lanjut supaya hasil pembacaan lebih akurat dan juga perlu penerapan Internet of Thing (IoT) untuk mekanisme pengontrolan.

\section{REFERENSI}

[1] anonim, "http://datatopics.worldbank.org/what-awaste/trends_in_solid_waste_management.html," 02112020. [Online]. Available: http://datatopics.worldbank.org/what-awaste/trends_in_solid_waste_management.html.

[2] anonim,"https://www.worldbank.org/en/news/feature/2019/05/ 31/meet-the-innovators-battling-plastic-waste-in-indonesiamohamad-bijaksana-junerosano," 0211 2020. [Online] Available:

https://www.worldbank.org/en/news/feature/2019/05/31/meetthe-innovators-battling-plastic-waste-in-indonesia-mohamadbijaksana-junerosano.

[3] J. Bobulski dan M. Kubanek, "Waste Classification System Using Image Processing and Convolutional Neural Networks," Advances in Computational Intelligence, pp. 350-361, 2019.

[4] S. K. Kale, A. G. Deshmukh, M. S. Dudhare dan V. B. Patil, "Microbial degradation of plastic: a review," Biochem Tech, pp. 952-961, 2015.

[5] S.-Y. Tsai, H. Ti Yu dan C.-P. Lin, "Environmental influence analysis of marine waste-oyster shell-plastic bag for waste treatment," Journal of Thermal Analysis and Calorimetry, 2020.

[6] A. K. Tripathi, A. Tiwari dan R. Shankar, "Treatment of Plastic Wastes by UV Catalyzation and Aspergillus Niger," Journal of Basic and Applied Engineering Research, pp. 57$61,2019$.

[7] J. J. Klemeš, Y. V. Fan dan P. Jiang, "Plastics: friends or foes? The circularity and plastic waste footprint," Energy Sources, Part A: Recovery, Utilization, and Environmental Effects, 2020. 
Vol. 01, No. 2, 27 Desember 2020

Politeknik Negeri Cilacap

[8] F. Seik, "Recycling of domestic wastes: Early experiences in Singapore," Habitat International, pp. 277-289, 1997.

[9] S. \&. H. B. Thomas, "Household Waste Management in a Swedish Municipality : Determinants of Waste Disposal Recycling and Composting," Environmental and Resource Economics, pp. 473-491, 2017.

[10] F. T. P. D. Zahra, "Kajian Komposisi, Karateristik, dan Potensi Daur Ulang Sampah di TPA Cipayung,Depok,” Jurnal Teknik Lingkungan, vol. 17, pp. 59-69, 2011.

[11] H. Bhardwaj, R. Gupta dan A. Tiwari, "Communities of Microbial Enzymes Associated with Biodegradation of Plastics," Journal of Polymers and the Environment, pp. 575579, 2013. 